\title{
Tax Revenue Sustainability: The Role of Tax Education and Enlightenment
}

\author{
Rufus I. Akintoye Luke N. Onuoha* \\ Department of Accounting, Babcock University, Ilishan Remo, Ogun State
}

\begin{abstract}
Tax revenue sustainability is considered as a necessary imperative for attainment of economic sustainability. This requires an environment where both taxpayers and tax officials have appropriate knowledge of their roles and responsibilities. This study was aimed at establishing the effect of tax education and enlightenment on total tax revenue. The survey design was adopted and through a close-ended questionnaire primary data were collected and analyzed using descriptive and inferential regression analysis. The results showed that tax education and enlightenment positively and significantly affected the total tax revenue. Radio and television were revealed as the strongest tax education channels. The study recommended that the Federal Government of Nigeria should set up and sufficiently fund an autonomous department to handle all tax education and enlightenment issues as this can enable the unit function more vigorously. The study portends beneficial significance to Nigeria's tax policy makers, national economic planners and academic researchers.
\end{abstract}

Keywords: tax revenue; sustainability; tax education; enlightenment.

DOI: $10.7176 / \mathrm{RJFA} / 10-2-05$

\section{Introduction}

Sustainable development warrants focusing attention of policy makers and government to achievement of prosperity in the society, such that the objective of taxation which serves as the major source of revenue for most countries is focused on provision of public goods and infrastructure to meet the expectations of the present and the future hopes of the society.

The critical test of this study was to determine how the tax system's imperatives made up of tax education and enlightenment, tax incentives, tax law and reforms, tax administration and information technology affected sustainable tax revenue which in turn affected sustainable development. Sustainability focuses at an array of concepts fit harmoniously to project the needful social responsibility that would augur for long term success of the tax system. Wong, Pippin, Webber and Bergner (2016) affirmed that the inclusion of sustainability into business strategies was new. There was very little doubt that aiming at sustainable development meant seeking increase in tax revenue and ensuring, at the same time, that the taxpayers were happy to continue with positive cooperation with the government.

In this study, attempt was made to determine the effect of tax revenue on the wellbeing of the citizens. Unlike companies where a host of variables ranging from assets tangibility, turnover, cost of operation, return on equity, return on assets, dividend per share and firm value, constituted major measurement variables of sustainability, focus in the case of government was directed at the three pillars bothering on social, economic and environmental developments (Akintoye, 2018; Azubike, 2009; Pfister, 2009).

In Nigeria, things do not appear to have moved on well in all the three parameters enumerated in the foregoing paragraph. There have hardly been any good roads; electricity has been epileptic; schools have been poorly funded; public hospitals have remained without drugs; and ecological concerns were growing daily. There were claims that it was only in Lagos, Rivers and Akwa Ibom States that the state governments had inspired the citizens with improved electricity, good roads, and clean environment (Akpu \& Ohaka, 2017; Nwidobie \& Oyedokun, 2018). Provision of similar infrastructures on a long term basis was what the public expected from the Federal Government with increasing tax revenue (Fiorino, 2010).

Important nexus could be established between the tax system and sustainable development given that the sustainable development goals would be unattainable without sustainable tax revenue. Tax revenue is a portion of the total revenue accruing to the government. Taxes accrued from companies income tax, personal income tax, petroleum profits tax, customs and exercise duties, withholding tax from corporate entities and Federal Capital Territory, and Value Added Tax (Mainoma, 2018; Eneje \& Ekwueme, 2018). Ozele, Ralph, and Atu, (2018) underscored the fact that adequate tax revenue generation was predicated on the nature of the tax law and regulations. Somorin (2012) noted that government should be transparent in accounting for the revenue it generated through taxation by investing in the provision of infrastructure, public goods and services. The importance of so doing by government was that it would earn public trust which in turn would attract more tax revenue for national development.

Some researchers have suggested that government depended to a large extent on tax revenue to carry out its social, economic, and environmental developments (Akintoye, 2018; Sani \& Awa, 2018; Akpu \& Ohaka, 2017). Omesi and Nzor (2016) attested to the significance of tax revenue but decried the huge sums of tax revenue that 
were lost annually due to under-assessment of payable duties, unauthorized transfers of funds, abuse of waivers, concessions, exemptions and non-remittances. The studies of Abiola and Asiweh (2012) and Umar and Saad (2015) argued that growth of tax revenue could be affected by the enforcement strategy of the administration.

Taxation experts have asserted that effective tax system was the bedrock of sustainable development in all countries of the world (Akintoye, 2018; Fiorino, 2010). Jelilov, Abdulrahman and Isik (2016), Lenon (2012) and Nwosu, Tondo and Wali (2016) affirmed that taxation was considered globally as a strong source of revenue to the government. Ijeh (2014) defined taxes as compulsory levies imposed by the government on persons and companies for the purpose of revenue generation. This perspective has attracted tremendous studies focusing on taxation and gross domestic product (GDP). Jelilov, et al., (2016) pointed to improvement of revenue generating capacity of government as the outcome of tax reforms. Their recommendation was a regime of taxes in line with the government's macro-economic agenda for there to be sustainable economic growth. Several other studies on taxation focused mainly on revenue generation and failed to show how the different taxation variables and tax revenue affected sustainable development (Abdullateef, 2018; Edori, Edori \& Idatoru, 2017).

Some advanced economies (United Kingdom, France, United States and Canada, for instance) had mustered huge revenue from taxation because of the high tax compliance rate among the citizens and due partially to the high level of awareness of the societies (Bagchi, 1993; Fiorino, 2010; Mathieu-Bolh, 2017). The rate of compliance was associated with the assessment of the citizens of the performance of the government. In this sense, compliance rate would be high where the rating of the government was positive and low where it was negative. Put differently, a negative assessment of the government's development efforts would come with a low tax compliance rate, high evasion and low tax revenue, and the job of the government to deliver on the infrastructures would be made more unattainable.

The trend from the emerging economies appeared to be the same as for the developing economies. While the importance of taxation as basic revenue earner for the government was understood, much focus appeared to be on how to make this sustainable for economic development in the countries (Bouet \& Roy, 2012; Mahfar, 1994; Mikesell, 1974). Bouet \&Roy (2012) maintained that there was positive elasticity between evasion and tariffs in Kenya and Nigeria while there was weaker evidence from Mauritius. The strength of the argument from the emerging economies lay on tax revenue being seen as a strong imperative for sustainable development of the economy. This notion found agreement with the views of Lenon (2012) who opined that a functional tax system was of critical essence to the development of a strong civil society. Bostan (2016) showed high relationship between financial stability and tax laws by his focus on massive changes in the provision of tax codes. The result was a remarkable improvement in sustainability, efficiency and prudence. These studies pointed to the need for shifting the focus from relationship between tax revenue and GDP to the link between sustainability of tax revenue and sustainable development of the nations.

A number of studies in Africa favoured the need for refocusing towards sustainable tax revenue for sustainable development (Afuberoh \& Okoye, 2014; Dopemu \& Monday, 2018; Pfister, 2009). While so many studies in Nigeria appeared to focus more on total tax revenue and the GDP, a handful number showed need for more relevant studies to drive sustainability. Ezejiofor, Adigwe, \& Echekoba (2016) revealed that taxation as a fiscal policy instrument had a significant influence on the performance of Nigerian manufacturing companies. Ekeocha, Ekeocha, Malaolu and Oduh (2012) found that tax bases were not stable. Akintoye (2018) and Mainoma (2018) pointed at consumption tax as reliable sustainable tax revenue earner, but Umoru and Anyiwe (2013), however, were not optimistic that indirect tax had the solution as their study found that indirect taxation was insignificant as far as economic growth in Nigeria was concerned.

Azuka (2015); Kupoluyi, Oloyede, \& Oyedokun (2018); Okoye, Akenbor \& Obara (2012); and Sani (2012) presented serious issues prevailing against the realization of an effective taxation system in Nigeria. The issues included multiple taxation; inadequate skilled manpower; lack of appropriate data on the taxpayers; tax evasion and tax avoidance. Afuberoh \& Okoye (2014) and Ezeagba (2014) had previously espoused the same views. Olatunji and Adegbite (2014) observed that no government could create a sustainable development without appropriate system of taxation.

Several studies on taxation raised questions on the sufficiency of tax revenue for meeting the government expenditure needs (Afeberoh \& Okoye, 2014; Jelilov et al., 2016; Okafor, 2012; Okolooba et al., 2018). Some other researches pointed to the existence of serious problems including multiple taxation, inefficient tax administration, shortage of manpower, statistical draught, low compliance and high evasion rates as major constraints to tax revenue generation (Adediran \& Oshode, 2013; Atawodi \& Ojeka, 2012; Ezeaga, 2014; Micah, Ebere \& Ubong, 2012; Mikesel, 1974). Adeosun (2017) put the total tax revenue at about 6\% of the Gross Domestic Product (GDP) of Nigeria. Okafor (2012) revealed very positive and significant relationship between tax revenue and the GDP. For many years tax system in Nigeria was neglected until the fall in world oil prices since 2015 made the revenue inadequacy worse for the federal government. The situation became inevitable for the government to turn to taxation to seek to fill the shortfall in the revenue gap. Before this period, the tax system was neglected and left almost non-functional. The problem of inadequate tax revenue still remains 
unsolved. There have not been sufficient studies which provided appropriate evidence on tax revenue inadequacy.

Studies have suggested tax education and enlightenment as major tax system's imperative for driving sustainable tax revenue (Aderibigbe, Oke \& Oyedokun, 2018; Akintoye, 2018; Decman \& Klun, 2015; Nwanna \& Richards, 2010; Sanni, 2017). Yet it is not clear to what extent tax education and enlightenment had impacted on total tax revenue. Mahfar (1994) asserted that tax education was difficult because of the lack of actual data and presence of underground economies. The study, however, further suggested that tax education could curb the rate of tax evasion, promote tax compliance and raise the tax revenue. Akintoye (2018) considered that the inculcation of tax education in the curriculum of all academic levels and door to door awareness drive throughout the country could raise the standard of tax education and enlightenment among the citizens. It has been suggested that there were some individuals who were not sure of what the tax law said or which taxes they were obligated to pay (Umar \&Saad, 2015). Nwidobie and Oyedokun (2018) proposed that direct education by the tax authority was the most effective channel of tax education. Some business owners were not able to determine what windows of opportunities the tax provisions had for their businesses or the types of taxes, mode, amount and effective due date for payment. The tax education problem still persists and there have not been adequate empirical studies to resolve the problem.

The foregoing discussion pointed out that numerous problems existed in connection with generation of sustainable tax revenue bothering on tax education and enlightenment. Equally, the reviews showed that experts had divergent views on the subject which called for further study. This study, therefore, attempted to address the problems raised and provided measurable evidences on how sustainable tax revenue could be attained through appropriate focus on education of the taxpayers and the tax authority personnel. This study was driven by the focal question on how tax education and enlightenment affected tax revenue generation in Nigeria. The resulting data from the survey carried out was tested to validate or reject the null hypothesis $\left(\mathrm{H}_{0}\right)$ that tax education and enlightenment have no significant effect on tax revenue in Nigeria.

\section{Literature/Theoretical Underpinning}

In this section focus is on the review of the relevant concepts, the theoretical framework and the empirical literature.

\subsection{Conceptual Review}

This section provided the relevant concepts that drove the understanding of the topic. Omesi and Nzor (2015) opined that a good tax system comprised of the tax law, tax policy and tax administration. Mikesell (1974) reiterated that the size of the tax base was the product of the levels of economic goods and flows within the taxing environment. The general focus of this review was on the Nigerian Tax System. Somorin (2012) and Abiola and Asiweh (2012) opined that the tax system comprised of the tax law, tax administration and the tax policy. Afuberoh and Okoye (2014) defined tax administration as the process of assessing and collecting taxes from taxable individuals and companies by ensuring that appropriate tax amounts were collected through efficient and effective processes, in such a way mitigated tax avoidance and evasion. This includes tax education and enlightenment as such critical engagement for the expected results of efficient administration.

In the attempt to provide answers to the critical challenges confronting the achievement of the lofty objectives of the 2012 policy to grow internally generated revenue; provide clarification on taxation powers of each level of government; provide sufficient information to taxpayers on how tax compliance requirements improve accountability of tax revenue; boost capacity of the tax administration to avoid delegation of powers of revenue officials to third parties; end the use of aggressive and unorthodox methods for tax collection; authorities to honour refund obligations to taxpayers; timely review of tax legislation, to ensure laws meet economic realities; and strict adherence to tax policy directional procedural guidelines. The guidelines were reviewed in 2016 and 2017 in the attempt to achieve a harmonious focus in consonance with the tenets of certainty and clarity as espoused in the 1776 tax canons by Adam Smith.

Smith (1776) proposed a set of tax principles known as the "cannon of taxation" which had remained since of general application world-wide. The principles held that each tax payer should contribute to the support of government fairly in proportion to their ability to pay. The cannons implied equity which Musgrave and Peacock (1984) described as equal proportion of taxation on every taxpayer's earnings. Similarly, Prest and Barr (1985) shared the same view that equal amount should be levied per head considering that such would be an easier to run system where each taxpayer paid the same amount, as against the one in which amount paid varied according to different economic circumstances of the taxpayers. Other features of the postulation by Smith (1776) were the principle of certainty, principle of convenience, economy, revenue generation, wealth redistribution, economic price stability, economic growth and development.

Other important tax concepts touched are tax Law and reforms, tax policy, tax administration and information technology. 
Somorin (2012) referred to tax law as system of codified enactments which specify mandatory levies imposed on transactions of economic nature. The laws are a set of legislations enacted by the legislature which imposed claims on taxpayers in favour of the government. Alabede, Ariffin \& Idris (2011) placed the tax law at the centre of definition of tax compliance. According to them, it was the law that provided the standard and the basis of enforcement to achieve what could be described as compliance. Otubu (2018) alluded to this understanding by stating that tax was a charge on income, property or transactions which was ascertainable, specific and enforceable at the pain of penalty imposed by law. In Nigeria, each tax law was backed by an enabling legislation which regulated how to apply the tax law provisions. The tax laws required careful drafting to ensure that the intentions of the drafters were clearly communicated to the taxpayers.

In effect, all the changes were intended to expand the non-oil resource base of the Nigerian economy. Omesi et al., (2015) stated that tax reforms were not avoidable. Okafor (2012) empirically investigated the impact of tax reforms in Nigeria's economic growth and submitted that the reforms had positive impact in economic stimulation. Despite the slow process associated with some past reforms, the government has often engaged in so doing after due consideration of the implications to the citizenry and the government resource generation needs. Tax education and enlightenment have consequential effect on the taxpayers' understanding of the laws and tax compliance.

Tax administration is comprised of the entire organizational apparatus for the management of the tax system. The set-up functioned as a department of the government regulated by the tax legislations (Akintoye, 2018). Tax administration involved the processes of assessment and collection of taxes from individual and corporate taxpayers. The goal was normally to ensure that the correct amount of taxes was collected as efficiently and effectively as possible with very minimum tax avoidance and evasion (Abdul, 2018; Oyedele, 2015). Kupoluyi, Oloyede and Oyedokun (2018) asserted that a good tax regime involved timely and correct payment of taxes and further submitted that good tax administration would harness increased tax revenue by discouraging tax avoidance and evasion.

The Tax Administration fell on the shoulders of the various tax authorities of the Federal, State and Local Government tiers of government. These tax authorities are the Federal Tax Authority, being the Federal Inland Revenue Service (FIRS); the State Tax authority, known also as State Board of Internal Revenue; the Local Tax Authority, which functioned through the Local Government Revenue Committee. The three authorities administered the tax laws and advised the government on all relevant matters of taxation (Somorin, 2012).

Abdul (2018) remarked that effective tax system was possible through administrative efficiency which involved taxpayer education, engagement of trained personnel and use of modern technology. Abiola, et al., (2016) asserted that effective tax administration aimed at bringing more people into the tax net and ensuring very minimal tax avoidance and evasion. Oyedele, 2015 pointed out that the function of a tax administrator was making sure that the taxpayers were in full compliance to the tax provisions. The processes were normally by making the tax assessment and payment easy for the taxpayers (Alabede, Ariffin \& Idris, 2011). A tax administration that encouraged taxpayers to willful self-assessment and tax payment was considered appropriate. Often such attainment would be possible only by the persuasion of efficient and effective administration.

Akintoye (2018), Abiola and Asiweh (2012), Micah, Ebere and Unobong (2012), Enahoro and Jayeola (2012), and Alabede, Ariffin and Idris (2011) observed that tax administration in Nigeria was fraught with so many problems. These included low skilled manpower, lack of clarity of powers of the different levels of government, non-review of tax legislations, corruption and collusion with external persons which resulted in loss of revenue to the government, poor work ethics which affected productivity, very poor customer service delivery, deficiency of information gathering, poor registration of taxable persons, filing and returns processing, ineffective communication across the entire tax administration which gave rise to poor coordination, high level of tax evasion and multiple taxation, lack of automation of processing and accounting of tax revenue collected. Okoye, Akenor and Obara (2012) strongly lamented the cases of lack of transparency and accountability of funds, poor funding of tax boards, absence of functional tax audit, lack of reciprocity and legitimacy, as well as public trust and corrupt practices of tax officials, to mention a few. Adegbie and Adebayo (2018) revealed that the twin problems of tax evasion and ineffective administration had led to dismal mobilization of tax revenue to complement oil revenue for financing of capital infrastructure by the government.

Tax Administration ensured taxpayer education and formulated strategies to enable enforcement of correct assessment and collection of taxes. Mahfar's (1994) investigation of a taxpayer education program for developing countries in Malaysia noted that a study of tax education was difficult due to lack of actual data, a point corroborated by Hamadu and Okafor (2009) and Micah et al., (2012). Assessing by a study of the effect of tax administration on taxpayers' compliance in Nigeria, Kupoluyi et al., (2018) submitted that there was a functional linkage between tax administration and tax compliance. The examination of effect of tax administration on sustainable development formed a critical engagement in this study.

Tax policy embodies the principles that guided a country's tax system (Somorin, 2012). It was the approach by which the taxation of a country was delivered. It defined the items that would be taxed, the rates at 
which they would be taxed and the measure of exemption and reliefs that applied to the different categories of taxes, taxpayers and tax reliefs. Tax policy attempted to simplify the tax burden by keeping rates low as doing otherwise could encourage tax avoidance and evasion. The study by Umoru and Anyiwe (2013) showed that tax policy of direct taxation affected taxation significantly while indirect taxation was insignificant. Also Atawodi and Ojeka (2012) found that tax rates and complex filing had crucial impact to non-compliance among SMESs in Zaria.

The National Tax Policy $(2016 ; 2017)$ detailed the specific objectives to drive orderly development of the Nigerian Tax system which included clarification on the operation and review of the tax system; provided information on the basis for future new legislations and administration; assisted all stakeholders know how to engage with all tax matters, and served as a benchmark for everyone to understand their roles and responsibilities.

Mainoma (2018) summarized the major taxes into three categories, namely: taxes based on income, capital and consumption. The taxes based on income were the personal income tax, companies' tax and petroleum profit tax. The consumption-based taxes were imposed on goods and included the value added tax (VAT), excise duties and custom duties. Capital taxes were those imposed on property such as capital gains and rents of property. Tax policies were clarified and made more functional through the instrumentality of tax reforms.

The entire gamut of the reforms in Nigeria provided evidence of the objectives of the reforms as directed at expansion of the tax revenue and support of government budgetary needs; encouragement of voluntary compliance by taxpayers; effort to combat corruption, eliminate it if possible; reduction of reliance on oil revenue; expansion of the tax net; plugging the leakages within the tax system; re-orientation of the tax authorities personnel towards positive change; service delivery improvement; and above all, removal of multiple taxes. Jelilov et al., (2016), Mathieu-Bolh (2017), and Omesi et al., (2016), appeared to agree to these facts and posited further that tax reforms were very critical to increased tax revenue and introduction of best practices into the tax system.

\subsection{Theoretical Underpinning}

The underpinning theory of the study is the benefits theory of taxation. The theory was propounded in 1919 by Erik Robert Lindahl, a Swedish political economist. The theory was persuaded by a consideration of the nature of the relationships between the government and the citizens (Giersch, 2007; Johansen, 1963). The search was for an equilibrium in the pricing of public goods. The theory grew out of Lindahl's tax conception described as a form of taxation whereby the individual paid for public goods in proportion to the marginal benefits derived. In other words, the tax amount payable by an individual was in direct equilibrium with the measure of utility he derived from each additional unit of public good consumed.

The benefits theory assumed a form of quasi contractual relationship between the government and the taxpayers. This implied that the government should provide certain goods and services to the society and the members of the public paid for the services in proportion to their benefits (Bhartia, 2009). Anyanfo (1996) affirmed the same notion that taxes should correspond to benefits received from the government. It would appear that the negative result of non-performance by the government as is easily seen from developing countries would mean that the government would have no taxes to collect. Such strict interpretation would be a discouragement against the contemplation of the benefits theory when considering cases of places like Nigeria and other developing economies where there was apparent breach in government's provision of public goods and individuals funded most of their social needs directly.

\subsection{Empirical Review}

There was a widely held view by experts and researchers that more tax revenue would be generated for the government where taxpayers were better informed about the essence of taxation. Nwidobie and Oyedukun (2018), in a study of the effectiveness of tax education channels in Nigeria, employed primary data analyzed using effectiveness of marketing metrics, and found that direct education by the tax authority was the most effective channel of tax education. Areas of education necessary were identified in the study as types of taxes, mode and amount of payment, effective due date for payment and benefits of tax paid. The study further found that there was need for the tax administrators to accurately answer taxpayers' questions. The study then concluded that tax administrators would need to directly educate the taxpayers about need for compliance to their tax obligations. The study concentrated its survey in the industrial clusters of Lagos only. Given the likelihood of persons within such locations chosen being far educated and informed, it was doubtful if the choice of only highly literate population of Ikeja, Lagos for sampling would provide balanced perceptions of the population of Nigeria. This gap was considered better taken care of by a more widely spread survey.

In another study of the SMEs in Edo State, Anyaduba and Balogun (2018), using correlation matrix and Ordinary Least Square regression analysis found a positive and significant relationship between electronic taxpayer education and tax compliance, and between stakeholder sensitization programme and tax compliance in Edo State. The study, however, revealed that print media taxpayer education and tax compliance were positive 
but statistically not significant. The study concluded that in order to instill a culture of sustainable tax compliance among the SMEs in Edo State and in Nigeria generally, taxpayer education and awareness should be pursued with greater vigor, more so, in respect of the print media. Like the study by Nwidobie et al., (2018) which obtained data from Lagos city alone, Anyaduba et al., (2018) study also shared in the same limitation as the data came only from Edo State. The same argument of limited scope and inadequacy of evidence to generalize for the whole country applied given that there were 36

From exploratory study of taxing for sustainability, Akintoye (2018) observed that for taxation to be used as a way of financing sustainable development, Nigerians had to be educated on the benefit of paying taxes. Saidu and Dandago (2018) saw that tax education and enlightenment were so crucial that it should be included in the educational syllabuses across all levels of academic learning; that clerics should teach and preach the need to pay taxes while the tax administrators should carry the campaign from door to door. The study, however, would have assumed more force of mandate if it was backed by statistical evidences. This gap made necessary the need for more studies in the area.

Ezeagba (2014) noted in an earlier study of the generation of tax revenue in Nigerian private sector, using primary survey, that one of the reasons self-employed people avoided or evaded tax was lack of taxpayer education. The gap in the study stemmed from its narrow focus on only self-employed private sector. The study was not representative of the whole country.

Nwanna and Richards (2010) study focused on the imperative of basic tax education for the citizens. The study was exploratory and made the point that lack of basic understanding of taxes was unwarranted, long overdue and importantly could be costing the taxpayers heavily. The study focused on personal income tax in the United States of America as one that was most recognized and which accounted for a significant amount of tax paid by Americans. The observation of the authors as regards what was lost by taxpayers was very noteworthy. Without good tax education, a large number of taxpayers would fail to appreciate the importance and role of tax revenue to the government. The paper stated that, being generally tax averse, many people would not appreciate the role of government, the services provided and the fact that all services had to be paid for. That called for continuous education and reeducation of the people and the tax managers.

The study of Nwanna et al., (2010) further asserted that lack of basic tax education came with lack of tax planning and led to many taxpayer citizens not able to take advantage of the various tax breaks, credits or legal loopholes that could give them huge tax gains. The fact that many tax preparers themselves were not very well informed of the tax laws and system, these taxpayer losses went on from year to year. The paper addressed tax education advantages to the government as better tax-informed and tax-knowledgeable citizens, higher level of tax compliance individuals, reduction in rate of non-compliance and cost of effecting compliance, better appreciation of government initiatives and more especially, better chances of very improved tax revenue collection. The study lacked empirical data. The points made appeared to be the personal views of the authors and not of field studies. In addition, the study focused on the case of United States of America. It was doubtful to what extent the context would be appropriated to the Nigerian environment. A more focused study involving data collection and analysis based on the Nigerian environment would be of greater relevance.

\section{Methodology}

\subsection{Design, Population and Sample Size}

The study adopted the survey design. Primary data was collected through the aid of questionnaire. The population of the study comprised of 108,399 members of Charted Institute of Taxation of Nigeria (CITN), Institute of Chartered Accountants of Nigeria (ICAN), and Association of National Accountants of Nigerian (ANAN), Senior Staff of the Federal Board of Inland Revenue (FIBR), and Nigerian Customs and Excise Department (CED). A sample of 498 was selected using the Yamane (1967) formula with 10\% adjustment for unforeseen vagaries. The apportionment of the sample size from each of the sub-population groups is shown in Table 3.1. 
Table 3.1: Apportionment of Sample Size to Population Sub-Groups

\begin{tabular}{|l|c|c|}
\hline Group & $\begin{array}{l}\text { Active } \\
\text { Population }\end{array}$ & $\begin{array}{c}\text { Apportioned } \\
\text { Sample Size }\end{array}$ \\
\hline & & \\
CITN & 20,803 & 84 \\
ICAN & 45,103 & 182 \\
ANAN & 32,168 & 130 \\
FIRS & 6,120 & 25 \\
CUSTOMS \& EXCISE (LAGOS) & 4,205 & 17 \\
\hline Total population & 108,399 & \\
& ---- & 398 \\
Total from sample population & ---- & 40 \\
Adjustment (10\%) & & $\mathbf{4 3 8}$ \\
\hline Grand Total & $\mathbf{1 0 8 , 3 9 9}$ & \\
\hline
\end{tabular}

Source: Researcher Computation (2018)

\subsection{Data Collection Instrument and administration}

The research instrument used in data collection was a structured questionnaire. This structured questionnaire was a self-developed by the researcher and was used to collect information in terms of the perceptions of the respondents on the items that measured tax education and enlightenment and sustainable tax revenue.

The structured questionnaire was designed in line with the five Likert-type scale where 1=Strongly Disagree; 2= Disagree; 3= Neutral; 4= Agree; and 5= Strongly Agree. The questionnaire was close-ended where the respondents were given the items/answers from which they were required to select appropriate options according to their view on each statement under evaluation for the primary data. It had been divided into sections: Section A was demographic profile of respondents in terms of gender, age, educational qualification, professional body affiliation and working experience after first degree. Section B was evaluation of the imperatives of tax education and enlightenment on sustainable tax revenue in Nigeria. The imperatives were seven items on education and sustainable tax revenue.

The questionnaire was administered by hand with the aid of research assistants to the relevant sample comprising of 84 to members of the CITN; 182 to ICAN members; 130 to ANAN member; 25 to senior staff of FIRS and 17 to senior personnel of the Customs \& Excise Board. Of the total 498 copies of the questionnaire issued out, 417 were returned successfully representing about $83.7 \%$ which was considered sufficient for the engagement.

\subsection{Data Analysis Method}

The study used descriptive statistics involving simple frequencies, and percentages. The bio-data distribution of the respondents (gender, age, marital status, educational qualifications and academic rank and length of service) was presented using frequencies and percentages as part of descriptive analysis. The evaluation of the responses was done by using frequencies, means and standard deviation for each statement. The test of hypothesis was carried out by using regression model for the objective. With simple regression analyses the researcher was able to explicitly control many other factors which simultaneously affected the dependent variable. Analysis of the data was carried out with the aid of the Statistical Product for Service Solution- SPSS version 23.

\subsection{Model Specification}

The variables of this study were guided by statistical model that was explained by the relational functions within the model. The data was gathered to help measure the effect of tax education and enlightenment on total tax revenue. Based on the measurements of variables, the following regression model was developed to guide the examination of the effects of the variables and to indicate the relationships that existed between them:

$\mathrm{Y}=\mathrm{F}(\mathrm{X})$

Where:

$\mathrm{Y}=$ total tax revenue, the dependent variable

$\mathrm{X}=$ tax education and enlightenment, independent variable.

The model is then restructured for regression analysis as:

STXR $=a+\beta_{0}$ TXE $\varepsilon$

Where:

STXR = sustainable tax revenue, the dependent variable

$\mathrm{TXE}=$ tax education and enlightenment, the independent variable.

$\alpha=$ constant

$\beta_{0}$ - the coefficient of the parameter estimates of tax education and enlightenment 
$\varepsilon=$ is the error term.

\section{Results/Findings and Discussion}

This sub sections shows the descriptive statistics interpretation on tax education and enlightenment in Nigeria based on the perceptions of the respondents.

Table 4.1 presents the descriptive analysis of the respondents on tax education and enlightenment in Nigeria using the tax and accounting professionals. The combination of the responses under agree and strongly agreed, the results that indicate that taxpayers' tax education and enlightenment are fundamental for tax compliance awareness are $84.9 \%$ of the respondents, while $8.9 \%$ of the respondents were neutral, and combining the responses under disagree and strongly disagree, $6.2 \%$ of the respondents disagreed with the statement. This indicates that on the average the respondents agreed with the statement with a mean of 4.18 and standard deviation of .904 . The findings show that taxpayers' tax education and enlightenment programs reduce errors by empowering taxpayers with tax knowledge. The respondents that agreed with the statement by combining those that agreed and strongly agreed answers are $82.5 \%$ of the respondents, $9.6 \%$ of the respondents were neutral while, $7.9 \%$ of the respondents by combining the responses of those that disagreed and others who strongly disagree with the statement, disagreed. This shows that on the average the respondents agree with a mean of 4.09 and standard deviation of 1.027

Table 4.1: Tax Education and Enlightenment in Nigeria

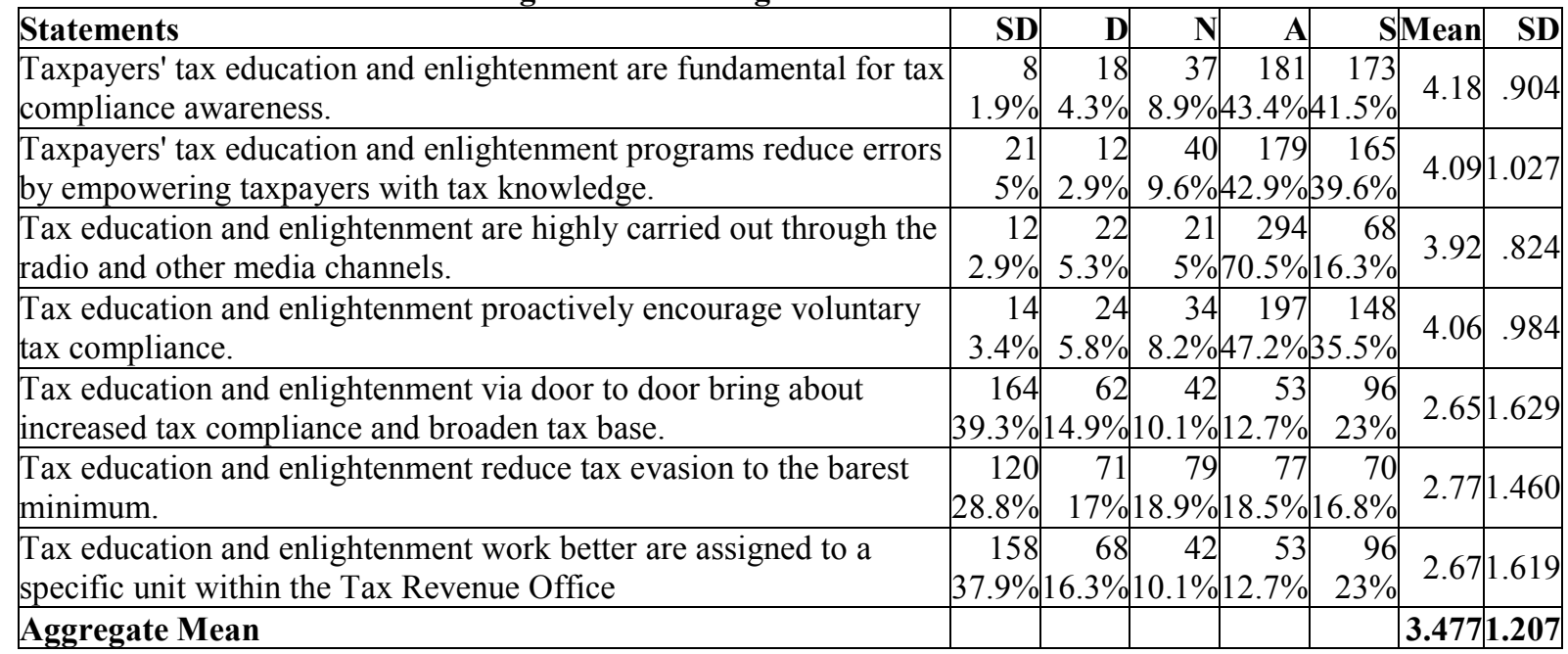

\section{Source: Field Survey, 2018}

The findings show that tax education and enlightenment are highly carried out through the radio and other media channels. By combining the responses of those that agreed and strongly agreed with this statement, $86.8 \%$ of the respondents agreed with the statement, 5\% of the respondents were neutral and by combining the responses of those that disagreed and others that strongly disagreed, $8.2 \%$ of the respondents disagreed with the statement. This indicates that on the average the respondents agreed with the statement with a mean of 3.92 and standard deviation of .824. The findings indicate that tax education and enlightenment proactively encourage voluntary tax compliance. This is accepted by $82.7 \%$ of the respondents combining those that agreed and others that strongly agreed with the statement, $8.2 \%$ of the respondents did not give their view (neutral) while, $9.2 \%$ of the respondents combining the answers of those that agreed and others who strongly agreed with the statement, disagree with the statement. On the average the respondents agree with the statement with a mean of 4.06 and standard deviation of .984 .

The findings indicate that tax education and enlightenment via door-to-door bring about increased tax compliance and broaden tax base. By combining the responses of those that agreed and others who strongly agreed with this statement, $35.7 \%$ of the respondents agreed with the statement, $10.1 \%$ of the respondents were neutral and combining the answers of those that disagreed and others that strongly agreed with the statement, $54.2 \%$ of the respondents disagreed with the statement. This is shown on the average by a mean of 2.65 and standard deviation of 1.629. The findings indicate that tax education and enlightenment reduce tax evasion to the barest minimum. For this statement, by combining the responses of those that agreed and others that strongly agreed with the statement, $35.3 \%$ agreed, $18.9 \%$ of the respondents were neutral and by combining the responses of those that disagreed and others that strongly disagreed with the statement, $45.8 \%$ of the respondents disagreed with the statement. On the average, the respondents disagreed with a mean of 2.77 and standard deviation of 1.460 .

The findings again indicate that tax education and enlightenment work better when assigned to a specific 
unit within the Tax Revenue Office. By combining the responses of those that agreed with the statement and others who strongly agreed with it, $35.7 \%$ of the respondents agreed with the statement, $10.1 \%$ of the respondents were neutral, while $54.2 \%$ of the respondents by combining the answers of those that disagreed and others who strongly agreed with the statement, disagreed with the statement. On the average, the respondents disagreed with the statement with a mean of 2.67 and standard deviation of 1.619. On the aggregate, the respondents agreed with a mean of 3.477 and standard deviation of 1.207 with tax education and enlightenment in Nigeria.

From the descriptive analysis it was established that the mean value of tax education and enlightenment is 3.47 (Table 4.1). This positive value shows that tax education and enlightenment contribute to tax revenue growth by enlightening the tax payers and tax personnel of their roles and responsibilities. The mean value of taxpayer's tax education and enlightenment as fundamental for tax compliance awareness is 4.18; this implies that tax education and enlightenment makes a highly appreciable impact on the tax compliance of taxpayers. The mean value of taxpayers' tax education and enlightenment programs reduction of errors by empowering taxpayers with tax knowledge is 4.09. This suggests that tax education and enlightenment highly empowers taxpayers with tax knowledge and thereby helps to mitigate errors which led to wrong assessment and tax payment. The mean value of tax education and enlightenment carried out through the radio and other media channels is 3.92. The implication of this result is that radio and other media channels make a high impact as sources of education for taxpayers.

The mean value of tax education and enlightenment proactively encouraging voluntary tax compliance is 4.06. This further implies that tax education and enlightenment encourages voluntary tax compliance among taxpayers. The mean value of tax education and enlightenment via door to door bring about increased tax compliance and broaden tax base is 2.65. This suggests an average contribution of door to door delivery of tax education to tax compliance and broadening of tax base. For tax education and enlightenment reducing tax evasion to the barest minimum, the mean is 2.77 . This implies an average contribution to reduction of tax evasion. The mean value of tax education and enlightenment working better when assigned to specific unit within the Tax Revenue Office is 2.67. This suggests an average effect to the tax education and enlightenment enforcement arising from the fact of it being driven from a separate unit of the Tax Revenue Office.

\subsection{Regression Results of Tax Education and Enlightenment}

Table 4.2: Combined Effect of Tax Variables on Tax Revenue in Nigeria

\begin{tabular}{|c|c|c|c|c|c|}
\hline \multirow[t]{2}{*}{ Model } & \multicolumn{2}{|c|}{ Unstandardized Coefficients } & \multirow{2}{*}{$\frac{\text { Standardized Coefficients }}{\text { Beta }}$} & \multirow[t]{2}{*}{$\mathrm{T}$} & \multirow[t]{2}{*}{ Sig. } \\
\hline & $\mathrm{B}$ & Std. Error & & & \\
\hline \multirow{6}{*}{$\begin{array}{l}\text { (Constant) } \\
\text { TXE } \\
\text { TXI } \\
\text { TXL } \\
\text { TXA } \\
\text { TXT }\end{array}$} & .613 & .364 & & 1.682 & .093 \\
\hline & .347 & .093 & .215 & 3.727 & .000 \\
\hline & .658 & .111 & .412 & 5.950 & .000 \\
\hline & -.314 & .111 & -.217 & -2.820 & .005 \\
\hline & .164 & .125 & .095 & 1.313 & .190 \\
\hline & -.056 & .090 & -.031 & -.619 & .536 \\
\hline \multicolumn{6}{|l|}{$\begin{array}{l}\mathrm{R}=.472 \\
\mathrm{R}^{2}=.223 \\
\text { Adj. } \mathrm{R}^{2}= \\
\mathrm{F}=23.480\end{array}$} \\
\hline
\end{tabular}

a. Dependent Variable: Tax Revenue

\section{Source: SPSS Output, 2018}

Table 4.2 gives detailed summary of the regression results analysis for the effect of tax variables (tax education, tax incentives, tax laws and reforms, tax administration and information technology) tax revenue in Nigeria. The results from Table 4.2 have demonstrated that tax education and tax incentives have positive and significant influence on tax revenue in Nigeria $\left(\beta_{1}=.347, \mathrm{t}=3.727, \mathrm{p}\right.$-value $<0.05 ; \beta_{2}=.658, \mathrm{t}=5.950$, $\mathrm{p}$-value $<$ $0.05)$ respectively. However, tax administration has positive but insignificant effect on tax revenue in Nigeria $\left(\beta_{4}\right.$ $=.164, \mathrm{t}=1.313, \mathrm{p}$-value $>0.05)$. The results indicate again that tax laws and reforms have negative and significant effect on tax revenue in Nigeria $\left(\beta_{3}=-.314, t=-2.820\right.$, p-value $\left.>0.05\right)$ and information technology has negative and insignificant effect on tax revenue in Nigeria $\left(\beta_{5}=-.056, \mathrm{t}=-.619, \mathrm{p}\right.$-value $\left.>0.05\right)$.

The magnitude of the estimated parameters suggests that 1 per cent increase in tax education and tax incentives will lead to $.347, .658$ per cent increase in tax revenue in Nigeria. Conversely, 1 per cent increase in tax laws and reforms will lead to .314 decreases in tax revenue in Nigeria.

The resulting regression model one (1) from the analysis is given as follows: TXR $=.613+.347$ TXE + .658 TXI -.314 TXL + .364 -----------Model 1

Where: 
$\mathrm{x}_{1}=$ Tax Education \& Enlightenment $(\mathrm{TXE})$

$\mathrm{x}_{2}=$ Tax Incentives (TXI)

$\mathrm{x}_{3}=$ Tax Laws and Reforms (TXL)

$\mathrm{x}_{4}=$ Tax Administration (TXA)

$\mathrm{x}_{5}=$ Information Technology (TXT)

The Adjusted $\mathrm{R}^{2}$ from Table 4.15 indicated that tax variables with reference to tax education, tax incentives, tax laws and reforms, tax administration and information technology have explained about $21.3 \%$ of variance in tax revenue in Nigeria (Adj. $\mathrm{R}^{2}=.213$ ), while, the remaining $78.7 \%$ of tax revenue is as result of other factors that have not been captured in the model. The correlation coefficient $(\mathrm{R}=.472)$ showed that there was a weak and positive relationship between taxation variables and tax revenue in Nigeria. The F- test of 23.480 is statistically significant with $\mathrm{p}<.05$ indicated that the variables used in the model have a goodness of fit and that are good predictors of tax revenue. Based on this the first null hypothesis which stated that tax variables do not have significant combined effect on tax revenue in Nigeria cannot be accepted.

\section{Implication to research and practice}

The findings of this study have implications to research and practice. The implications are relevant to the federal government, ministry of finance, tax planners, economic planners, academic researchers, and taxpayers. The study has revealed that tax education and enlightenment positively and significantly affect total tax revenue. The findings point to radio and television, and door-to-door enlightenment programs as effective channels for carrying out tax education and enlightenment programmes. The federal government is provided information on how the taxpayers and the tax officials could be educated and enlightened, such that tax compliance rate would increase. The tax policy makers are provided with information on how to advertise tax laws reforms in such manner that would receive the patronage of the public.

The Federal Ministry of Finance is provided with information that tax education and enlightenment contribute to tax revenue growth and help taxpayers and tax personnel to better understand their duties and responsibilities respectively. The information provided shows that tax education and enlightenment empowers taxpayers and leads to less assessment errors. The information provided shows that sustainable tax revenue can be achieved by improving on tax education and enlightenment.

Tax policy makers are provided with information that helps them understand that tax education would leads to increased tax assessment and payment by taxpayers. The findings also show that tax education proactively encourage voluntary tax compliance. Economic planners are provided with information that door to door tax education and enlightenment leads to increased tax compliance and tax base broadening. This informs that tax education leads to mitigation of tax evasion. The findings also provide information that tax education worked better when assigned to a specific unit of the tax revenue office. This can help the government when considering how to improve on the efficiency and effectiveness of the tax authority.

The study has contributed useful empirical literature in the area of tax education and enlightenment. These empirical evidences would be useful to researchers and help them have solid foundation for their future research.

\subsection{Conclusion and Recommendations}

The study examined the effects of tax education and enlightenment on total tax revenue. This provided statistical evidence and empirical bases for the implications of tax education and enlightenment on sustainable tax revenue. The study demonstrated that a positive and significant relationship existed between tax education \& enlightenment and tax revenue. This means that the effect of the tax education and enlightenment greatly influenced the tax revenue generation. The study implied that the individual tax education and enlightenment measures created different levels of effect on taxpayer knowledge of the expectations of the government and tax responsibility which ultimately affect tax morale and tax compliance. The findings provided a basis for the predictability of tax revenue given specific government's investments in the improvement of the tax education and enlightenment. It can be asserted, therefore, that by investing in the improvement of tax education and enlightenment, the government can attain sustainable tax revenue for deployment into socio-economic development of the country.

Based on the findings of the study, it is recommended that the Federal Government of Nigeria should pay more attention to the improvement of the tax education and enlightenment as this can hold the key to more tax revenue generation. Besides investing more resources on the training of the tax personnel, more awareness outlets on the radio, televisions and other mass media, the government should set up a special unit committed with tax education and enlightenment. This can help to ensure that tax education and enlightenment receives the right budgetary emphasis periodically and is carried out with more vigor to achieve more improved tax compliance by the taxpayers. 


\section{Future Research}

Future research interest should focus on the combined effect of all the tax imperatives (tax incentives, tax law and reforms, tax administration and information technology (IT)) to discover their separate and combined effect on total tax revenue. This direction would help the government and other stakeholders in the tax revenue generation project to act in appropriate ways that would encourage positive tax revenue growth.

\section{References}

Abdulateef, A. O. (2018, August 13-16). Tax administration in developing countries: towards improved tax compliance in Nigeria. Paper presented at the $1^{\text {st }}$ Annual International Academic Conference on Taxation at Nasarawa State University, Keffi. Retrieved from http://citn.org

Abiola, J. O. (2016). Widening the tax net: lessons from Lagos State, Nigeria. International Journal of Development and Management Review, 1(1), 198-207.

Adediran, S.A, Alade, S.O. \& Oshode, A.A. (2013). The impact of tax audit and investigation on revenue generation in Nigeria. European Journal of Business and Management, 5(26), 171-176.

Adegbie, F.F. \& Adebayo, O. (2018, August 13-16). Taxation and development of capital projects in Nigeria. Paper presented at the $1^{\text {st }}$ Annual International Academic Conference on Taxation at Nasarawa State University, Keffi. Retrieved from http://citn.org

Adeosun, K. (2017). No need to borrow if taxes are paid. International Monetary Fund and World Bank in Washington D.C. Conference.

Aderibigbe, T.A, Oke, M. A. \& Oyedokun, G. E. (2018). Tax base broadening through improved business environment in Nigeria. Paper presented at the $1^{\text {st }}$ Annual International Academic Conference on Taxation at Nasarawa State University, Keffi. Retrieved from http://citn.org

Afuberoh, D. \& Okoye E. (2014). The impact of taxation on revenue generation in Nigeria: A study of Federal Capital Territory and selected states. International Journal of Public Administration and Management Research, 2(2), 22-47.

Akintoye, I. R. (2018, August 13-16). Taxing for sustainability: the system imperatives in Nigeria. Paper presented at the $1^{\text {st }}$ Annual International Academic Conference on Taxation at Nasarawa State University, Keffi. Retrieved from http://citn.org

Akpu, U.G. \& Ohaka, J. (2017). Tax compliance strategy and tax revenue yield: empirical evidence from Rivers State, Nigeria (2007-2016). Pyrex Journal of Taxation and Accounting Management, 1(2), 9-23.

Alabede, J.O., Ariffin, Z.B.Z. \& Idris K.M. (2011). Determinants of tax compliance behaviour: a proposed model for Nigeria. International Research Journal of Finance and Economics, 78(1), 121-133.

Anyaduba, J. O. \& Balogun, J. E. (2018, August 13-16). Tax education and tax compliance among SMEs in Edo State. Paper presented at the $1^{\text {st }}$ Annual International Academic Conference on Taxation at Nasarawa State University, Keffi. Retrieved from http://citn.org

Anyanfo, A.M.O (1996). Public finance in developing economy: The Nigerian case. Enugu: Nigeria

Atawodi, O.W. \& Ojeka, S.A. (2012). Factors that affect tax compliance among small and medium enterprises in North Central Nigeria. International Journal of Business Management, 7(12), 87-96.

Azubike, J.U.B. (2009). Challenges of tax authorities and tax payers in the management of tax reform process. Nigerian Account, 42(2), 36-42.

Azuka, A. I. (2015). Achieving sustainable development through tax harmonization: potentials, paradoxes and policy imperatives. Afe Babalola University Journal of Sustainable Development Law \& Policy, 6(1), 272338.

Bagchi, A. (1993). Information technology in tax Administration: recent cross-coutry experience. Economic and Political Weekly, 28(33), 1640-1644. Retrieved from https://www.jstor.org/stabe/4400019.

Bhartia, H. L. ( 2009). Public Finance. (16th Edition). New Delhi: Vikas Publishing House PVT Ltd.

Bostan, L. (2016). Leveraging sustainability as budgetary resources through financial law instruments. Annals of Constantin Brancusi' University of Targu-Jiu Economy Series, 1, 33-42.

Bouet, A. \& Roy, D. (2012). Trade protection and tax evasion: evidence from Kenya, Mauritius and Nigeria. The Journal of International Trade and Economic Development, 21(2), 287-320.

Decman, M. \& Klun, M. (2015). The impact of information systems on taxation: a case of users' experience with an e-recovery information system. The Electronic Journal of e-Government, 13(2), 110-121.

Dopemu, S. O. \& Monday, J. U. (2018, August 13-16). Tax incentives and business growth in Nigeria: evidence from panel data analysis of selected quoted manufacturing companies. Paper presented at the $1^{\text {st }}$ Annual International Academic Conference on Taxation at Nasarawa State University, Keffi. Retrieved from http://citn.org

Edori, D. S., Edori, I.S. \& Idatoru, A. R. (2017). Issues and challenges inherent in the Nigerian tax system. American Journal of Management Sciences and Engineering, 2(4), 52-57.

Ekeocha, P.C., Ekeocha, C. S., Malaolu, V.O. \& Onyema, M. (2012). Revenue implications of Nigeria's tax 
system. Journal of Economics and Sustainable Development, 3(8)206-213.

Enahoro, J.A. \& Jayeola, O. (2012). Tax administration and revenue generation of Lagos State government, Nigeria. Research Journal of Finance and Accounting, 3(5), and 139.

Eneje, B. C. \& Ekwueme, A. (2018, August 13-16). Large tax revenue mobilization and growth in developing economy: evidence from Nigeria. Paper presented at the $1^{\text {st }}$ Annual International Academic Conference on Taxation at Nasarawa State University, Keffi. Retrieved from http://citn.org

Fiorino, D.J. (2010). Sustainability as a conceptual focus for public administration. Public Administration Review, Special Issue, 78-84.

Giersch, T. (2007, August 20). From Lindahl's Garden to Global Warming: how useful is the Lindahl approach in the context of global public goods? Retrieved from https:// editorialexpress.com/cigbin/conference/download.cig?db_name=IIPF63\&paper_Id=246.

Hamadu, D. \& Okafor, R. (2009). On statistical capacity building in Nigeria: a necessary step towards achieving millennium development goals (MDGs). Statistical Journal of the IAOS, 26(9), 21-32.

Jelilov, G., Abdulrahman, S. \& Isik, A. (2016). The impact of tax reforms and economic growth of Nigeria. The Empirical Economics Letters, 15(5), 89-101.

Johansen, L. (1963). Some notes on the Lindahl theory of determination of public expenditures. International Economic Review, 14(3), 346-358.

Kupoluyi, A. K., Oloyede, F. L. \& Oyedokun, G.E. (2018, August 13-16). Effect of tax administration on taxpayers' compliance in Nigeria. Paper presented at the $1^{\text {st }}$ Annual International Academic Conference on Taxation at Nasarawa State University, Keffi. Retrieved from http://citn.org

Lenon, C. (2012). Tax and development. OECD Yearbook, 74-75.

Mahfar, M. S. (1994). An investigation of taxpayer education program for developing countries: a Malaysian example. A dissertation submitted to Golden Gate University for the degree of Doctor of Public Administration.

Mainoma, M. A. (2018, August 13-16). Taxation and economic reality: a case for consumption tax. Conference inaugural address presented at the $1^{\text {st }}$ CITN Annual International Academic Conference on Taxation held at Nasarawa State University, Keffi. Retrieved from http://citn.org

Mathieu-Bolh, N. (2017). Can tax reforms help achieve sustainable development? Resource \& Energy Economics, 50(1), 135-163.

Micah, L. C., Ebere, C. \& Unobong, A. A. (2012). Tax system in Nigeria - challenges and the way forward. Research Journal of Finance and Accounting, 3(5), 9-15.

Musgrave, R.A \& Peacock, A.T (1958). Classics in Theory of Public Finance. International Economic Association Series. UK: Palgrace Macmillan .

Mikesell, J.L. (1974). Administration and the public revenue system: a view of tax administration. Public Administration Review, 615-624.

Nwanna, G \& Richards, D. (2010). The imperative of basic tax education for citizens. American Journal of Bussiness Education, 3(9),61-19.

Nwidobie, B.M. \& Oyedokun, G.E. (2018, August 13-16). The effectiveness of tax education channels in Nigeria. Paper presented at the $1^{\text {st }}$ Annual International Academic Conference on Taxation at Nasarawa State University, Keffi. Retrieved from http://citn.org

Nwosu, M. E. , Tondo, E. I. \& Wali, B. A. (2016). The challenges and imperative of tax system reform in Nigeria. International Journal of Economics and Finance, 8(3), 151-164.

Okafor, R.G. (2012). Tax Revenue Generation and Nigerian Economic Development. European Journal of Business and Management, 4(19), 49-56.

Okoye, P.V.C., Anenbor, C.O. \& Obara, L.C. (2012). Promoting sustainable tax compliance in informal sector in Nigeria. AFRREV International Journal of Arts and Humanities, 1(1), 40-54.

Olokooba, S.M., Awodun, M. \& Adebowale, H.I. (2018, August 13-16). Tax offences: clogs in the wheel of progress and development of Nigeria as a nation. NAUJILJ, 9(1), 226-236.

Omesi, I. \& Nzor, N.P. (2015). Tax reforms in Nigeria: case for value added tax (VAT). African Research Review, 9(4), 277-287.

Omesi, I. \& Nzor, N.P. (2016). Tax reforms in Nigeria: case against tax incentives. International Journal of Arts and Humanities, 5(1), 138-150.

Otubu, A. (2018). The Land Use Act and equity factor in property taxation in Nigeria. NUJILJ, 9(1), $217-225$.

Oyedele, T. (2015). Insights on taxation and fiscal policy. Great Britain: Bloomsbery Professional limited.

Ozele, E. C., Ralph, A., Atu, F. O. \& Atu, O. G. (2018, August 13-16). Value added tax and revenue generation in Nigeria: an empirical analysis. Paper presented at the $1^{\text {st }}$ Annual International Academic Conference on Taxation at Nasarawa State University, Keffi. Retrieved from http://citn.org

Pesaran, M. H., Shin, Y., \& Smith, R. J. (2001). Bounds testing approaches to the analysis of level relationships. Journal of Applied Econometrics, 16(3), 289-326. 
Pfister, M. (2009, November 3-19). Taxation for investment $n d$ development: an overview of policy challenges in Africa. Ministrial Meeting and Expert Roundtable of NEPAD-OECD Africa Investment Initiative on 11-12.

Prest, A.R. \& Bar N.A. (1985). Public Finance in theory and Practice ( $7^{\text {th }}$ Ed). Uk: Weidenfeld \& Nicolson

Sachs, J. D. (2015). The age of sustainable development. New York: Columbia University Press.

Saidu, A.J. \& Dandago, K.I. (2018, August 13-16). Personal income tax compliance by the informal sector operators in Bauchi Metropolis, Bauchi State, Nigeria. Paper presented at the $1^{\text {st }}$ Annual International Academic Conference on Taxation at Nasarawa State University, Keffi. Retrieved from http://citn.org

Sanni, A. (2012). Multiplicity of taxes in Nigeria: issues, problems and solutions. International Journal of Business and Social Sciences, 3(17), 229-236.

Sanni, A. (2017, November 17). Policy, legal and administrative imperatives in the quest for eradicating multiplicity of taxes in Lagos State. Paper delivered at the $1^{\text {st }}$ Annual Lecture of Lagos State Professor of Tax and Fiscal Matters. Retrieved from https://abiolasannindco.com

Smith, A. (1776). The Wealth of Nations. London: Penguin Books Ltd

Somorin, O.A. (2012). Teju tax reference book Volume 1. Lagos : Malthouse Press Limited.

Umar, M. S. \& Saad, N. (2015). Readability assessment of Nigerian Company Income Tax Act. Jurnal Pengurusan, 44(5), 25-33.

Umoru, D. \& Anyiwe, M. A. (2013). Tax structure and economic growth in Nigeria; Disaggregated empirical evidence. Research Journal of Finance and Accounting, 4(2), 65-79.

Wong, J, Pippin, S, Weber, J \& Bergner, J (2016). The inclusion of sustainability in the accounting curriculum. The CPA Journal, June Issue.

Yamane, T. (1967). Statistics: an introductory analysis $\left(2^{\text {nd }}\right.$ ed.). New York: Harper \& Row. 